\title{
KESESUAIAN PORSI LAUK DAGING AYAM YANG DITERIMA PADA MAKANAN BIASA
}

\author{
Rani Nurgianti Putri ${ }^{1 *}$, Reni Sofiyatin ${ }^{1}$, Lalu Khairul Abdi ${ }^{1}$, AASP Chandradewi ${ }^{1}$ \\ ${ }^{1}$ Jurusan Gizi, Poltekkes Kemenkes Mataram, Indonesia \\ Jl. Praburangkasari Dasan Cermen, Sandubaya Kota Mataram \\ Email : raninurgiantiputri@gmail.com
}

\begin{tabular}{l} 
Article Info \\
\hline Article history: \\
Received January $14^{\text {th }}, 2019$ \\
Revised February $17^{\text {th }}, 2019$ \\
Accepted March $9^{\text {th }}, 2019$ \\
\hline
\end{tabular}

Keyword:

Receipt Side Dish Chicken, Portion Standard

\begin{abstract}
Large portions are often one thing when serving food, especially in food serving. It is still an advantage and lack of portion because there is no right size in food processing. food consumption must be in accordance with the standard portion determined by the hospital nutrition installation. large portions will affect the nutrients contained in a food. This study aims to determine the suitability of standard portions of side dishes of chicken meat received in ordinary food at Sanjiwani Hospital Gianyar Regency. This study was a descriptive observational study with a crossectional approach. This research was conducted for 3 days in April 2019 at Sanjiwani Hospital Gianyar Regency. The number of samples is 30 servings. The proportion of portions served is measured by the food weighing method for 3 days. The results showed that the standard suitability of the portion of chicken received at Sanjiwani General Hospital in Gianyar Regency was largely incompatible, namely $83.3 \%$, while those in accordance with the standard portion were $16.6 \%$.
\end{abstract}

\section{Pendahuluan}

Penyelenggaraan Makanan Rumah Sakit merupakan rangkaian kegiatan mulai dari perencanaan menu sampai dengan pendistribusian makanan kepada konsumen dalam rangka pencapaian status gizi yang optimal. rangkaian kegiatan mulai dari perencanaan menu, perencanaan kebutuhan bahan makanan, perencanaan anggaran belanja, pengadaan bahan makanan, distribusi dan pencatatan, pelaporan serta evaluasi (Pelayanan Gizi Rumah Sakit, 2013).

Kegiatan dalam penyelenggaraan makanan yang berfungsi untuk menentukan kualitas bahan makanan adalah penerimaan bahan makanan. Apabila bahan makanan yang diterima tidak sesuai dengan spesifikasi yang telah ditetapkan maka akan mempengaruhi kualitas makanan yang disajikan kepada pasien. Penerimaan bahan makanan dapat digolongkan sebagai salah satu pengawasan yang dilakukan pada awal kegiatan penyelenggaraan makanan (Riqi, Maya. 2009).

Penerimaan yang dilakukan di RSUD Sanjiwani Kabupaten Gianyar pada lauk daging ayam dilakukan setiap hari, pada lauk daging ayam yang datang ditimbang beratnya untuk disesuaikan dengan pesanan, apabila berat bahan makanan yang dipesan lebih maka bahan makanan tersebut digunakan untuk hari berikutnya.

Pada saat penerimaan lauk daging ayam Besar porsi masih menjadi kelebihan dan kekurangan porsi karena tidak ada ukuran yang tepat dalam penerimaan lauk daging ayam . besar porsi lauk daging ayam harus sesuai dengan standar porsi yang telah ditentukan oleh pihak instalasi gizi rumah sakit. Besar porsi akan berpengaruh terhadap zat gizi yang terkandung dalam suatu makanan (Ambarwati,R. 2016)

Standar porsi dapat diartikan sebagai banyaknya makanan yang disajikan dan ukuran porsi untuk setiap individu. Untuk menentukan besar porsi yang akan disajikan kepada konsumen agar konsumen 
mendapatkan makanan yang sesuai dengan kebutuhan zat gizi baik dari segi kualitas suatu makanan maka dibutuhkan juga penyusunan standar porsi yang digunakan sebagai salah satu acuan. Oleh sebab itu untuk mencapai hal tersebut, maka setiap institusi penyelenggaraan makan harus menentukan standar porsi dari setiap makanan yang akan disajikan (Muchatob, 2001 dan Puckett, 2004. Eka Astuti, I A. 2018).

Berdasarkan uraian di atas yang mendasari peneliti untuk melakukan penelitian tentang gambaran kesesuaian standar porsi lauk daging ayam yang diterima pada makanan biasa di RSUD Sanjiwani Kabupaten Gianyar.

\section{Metode Penelitian}

Penelitian ini dilakukan dengan metode observasional deskriptif dengan pendekatan crossectional, penelitian yang dilakukan satu kali pada waktu yang bersamaan untuk mengertahui kesesuaian porsi lauk daging ayam yang diterima pada makanan biasa di RSUD Sanjiwani Kabupaten Gianyar. Penelitian dilakukan pada bulan april 2019 di RSUD Sanjiwani Kabupaten Gianyar. Obyek dalam penelitian ini lauk daging ayam yang diterima berdasarkan siklus menu untuk makanan biasa. Porsi lauk daging ayam yang diamati sebanyak 10 porsi dalam satu hari di RSUD Sanjiwani Kabupaten Gianyar.

Kesesuaian porsi lauk daging ayam diukur dengan menggunakan metode food weighing yang diterima selama 3 hari sebanyak 10 porsi dalam sehari.

Hasil penimbangan kemudian dibandingkan dengan standar porsi di RSUD Sanjiwani Kabupaten Gianyar kemudian dikategorikan menjadi 2 kelompok, yaitu : tidak tepat, jika yang dihasilkan $=<10 \%$ dan $>10 \%$ dari standar porsi. Tepat, apabila hasil penimbangan $= \pm 10 \%$ dari standar porsi (Wadyomukti, 2017)

Kesesuaian porsi lauk daging ayam yang diterima pada makanan biasa di RSUD Sanjiwani Kabupaten Gianyar diolah dan dianalisis secara deskriptif.

\section{Hasil Penelitian}

\section{Penerimaan Lauk Daging Ayam}

Proses penerimaan bahan makanan di RSUD Sanjiwani Kabupaten Gianyar dilakukan setiap hari sekitar pukul 08.00 yang dilakukan oleh ahli gizi yang bertugas. Bahan makanan yang datang akan dibawa kebagian penerimaan yang selanjutnya akan diperiksa kesesuaian bahan makanan yang datang dengan spesifikasi yang sudah ditetapkan. Akan tetapi bahan makanan yang tidak sesuai dengan spesifikasi yang sudah ditetapkan akan dikembalikan atau di tukar kepada rekanan.

Pada pesanan lauk daging ayam, apabila jumlah bahan makanan yang datang kurang dari pesanan maka rekanan harus mengantarkan bahan makanan tersebut pada hari yang sama. Adapun pada saat penerimaa harus memperhatikan daftar pemesanan bahan makanan dan daftar spesifikasi bahan makanan.

\section{Standar Porsi}

Tabel 1. Hasil Pengambilan Data Standar Porsi di RSUD Sanjiwani Kabupaten Gianyar

\begin{tabular}{ccc}
\hline Kelompok Bahan Makanan & Bahan Makanan & Jumlah (Gram) \\
\hline Lauk Daging Ayam & Paha Daging Ayam & 75 \\
\hline & Dada Daging Ayam & 50 \\
\hline
\end{tabular}

Berdasarkan tabel 1. Diketahui bahwa di RSUD Sanjiwani Kabupaten Gianyar terdapat lauk hewani yang salah satunya adalah Ayam, dimana ayam tersebut dibagi menjadi 2 bagian yaitu paha ayam dan dada ayam. Dari kedua

bagian ayam tersebut memiliki standar porsi yang berbeda-beda pada paha ayam standar porsinya 75 gram sedangkan untuk dada ayam yaitu 50 gram.

\section{Besar porsi}

Tabel 2. Rata-Rata Besar Porsi Lauk Daging Ayam Yang Diterima 


\begin{tabular}{ccc}
\hline Kelompok Bahan Makanan & Bahan Makanan & Rata-Rata (Garam) \\
\hline Lauk Daging Ayam & Paha Daging Ayam & 92 \\
\hline & Dada Daging Ayam & 57.8 \\
\hline
\end{tabular}

Berdasarkan tabel 2. diketahui bahwa rata-rata hasil penimbangan berat mentah selama 3 hari pada siklus menu (1, 9, dan 10) didapatkan pada paha daging ayam berat rata-rata sebesar 92 gram dalam satuu potong sedangkan untuk dada daging ayam sebesar 57.8 gram dalam satu potong.

Kesesuaian Standar Porsi Lauk Daging Ayam

Tabel 3. Kesesuaian Standar Porsi Lauk Daging Ayam

\begin{tabular}{lcccccc}
\hline Hari & & \multicolumn{2}{c}{ Jumlah } & \multicolumn{2}{c}{ Total } \\
\hline & & Sesuai & \multicolumn{2}{c}{ Tidak Sesuai } & \multicolumn{1}{c}{} \\
\hline I & $\mathbf{n}$ & $\mathbf{\%}$ & n & \% & n & \% \\
\hline II & 2 & 20.0 & 8 & 80.0 & 10 & 100 \\
\hline III & 2 & 20.0 & 8 & 80.0 & 10 & 100 \\
\hline Total & 1 & 10.0 & 9 & 90.0 & 10 & 100 \\
\hline & 5 & 16.6 & 25 & 83.3 & 30 & 100 \\
\hline
\end{tabular}

Berdasarkan tabel 3. diketahui bahwa persentase kesesuaian standar porsi selama penelitian berdasarkan siklus menu pada dada daging ayam dan paha daging ayam dilihat bahwa sebagian besar porsi lauk daging ayam tidak sesuai yaitu sebesar $83.3 \%$ sedangkan porsi lauk daging ayam yang sesuai sebesar $16.6 \%$.

\section{Pembahasan}

\section{Penerimaan Lauk Daging Ayam di RSUD Sanjiwani Kabupaten Gianyar}

Pada saat penerimaan lauk daging ayam yang dilakukan setiap hari sekitar pukul 08.00 yang dilakukan oleh ahli gizi yang bertugas. Dimana pada saat penerimaan ayam sudah dipotong - potong oleh rekanan sehingga besar potongan dari daging ayam yang diterima oleh petugas di Instalasi Gizi dalam bentuk dan ukuran yang berbeda-beda, kemudian ditimbang satu kali secara keseluruhan tanpa melihat spesifikasi per masing-masing potongan dengan alasan mengefisiensi waktu untuk pengolahan agar selese tepat waktu sehingga pendistribusian tidak terlambat. pada saat penerimaan ayam tidaksesuai karena sebagian besar melebihi standar porsi. dimana jika kelebihan standar porsi dapat mempengaruhi zat gizi yang terkadung dalam suatu makanan. Berdasarkan pengamatan terdapat faktor yang mempengaruhi ketidaksesuaian porsi yaitu kemampuan tenaga pemorsi yang tidak memperhatikan standar porsi yang telah di tetapkan di Rumah Sakit, dimana pada saat penerimaan lauk daging ayam tidak sesuai dengan potongan yang sudah diterima pada saat penerimaan oleh rekanan.

\section{Standar Porsi}

Standar porsi adalah rincian macam dan jumlah bahan makanan dalam jumlah bersih setiap hidangan. Dalam penyelenggaraan makanan orang banyak diperlukan adanya standar porsi untuk setiap hidangan, sehingga macam dan jumlah hidangan menjadi jelas. Porsi yang standar harus ditentukan untuk semua jenis makanan dan penggunaan peralatan seperti sendok sayur, centong, sendok pembagi harus distandarkan.

Berdasarkan tabel 1. Standar porsi untuk lauk daging ayam (paha ayam dan dada ayam) di RSUD Sanjiwani Kabupaten Gianyar untuk 1 kali makan yaitu 75 gram pada paha ayam dan 50 gram pada dada ayam.

\section{Besar Porsi}

Besar porsi adalah banyaknya golongan bahan makanan yang direncanakan setiap kali makan dengan menggunakan satuan penukar berdasarkan standar makanan yang berlaku di rumah sakit. Hal ini bertujuan sebagai acuan atau pedoman untuk memenuhi kebutuhan dan kecukupan makan pasien berdasarkan kebutuhan gizi yang direncanakan dengan standar porsi. Penilaian ini dilakukan dengan melakukan penimbangan terhadap berat mentah masing-masing hidangan kemudian mempersentasekan nilai besar porsi yang dihasilkan dengan standar porsi yang telah ditetapkan. Sebagian besar porsi masing - masing berat ayam yang ditimbang berat mentahnya untuk menu makanan biasa di RSUD Sanjiwani Kabupaten Gianyar . 
Berdasarkan tabel 2. Rata-rata besar porsi yang dihasilkan untuk lauk daging ayam pada bagian paha selama pengamatan 3 hari yang sesuai dengan siklus menu yaitu sebesar 92 gram dan pada bagian dada ayam yaitu sebesar 57.8 gram.

\section{Kesesuaian Standar Porsi}

Berdasarkan Hasil analisis pengolahan data dari observasi yang telah dilakukan yaitu ditemukan banyak perbedaan antara standar porsi makan rumah sakit yang telah ditetapkan dengan besar porsi lauk daging ayam yang diterima oleh petugas gizi. Perhitungan besar porsi dilakukan dengan penimbangan berat lauk daging ayam menggunakan alat timbangan makanan digital.

Berdasarkan tabel 3. Kesesuaian standar porsi yang telah ditetapkan, lauk hewani dikategorikan tidaksesuai dengan standar porsi yang telah ditetapkan di RSUD Sanjiwani Kabupaten Gianyar dimana ketidaksesuaian standar porsi yaitu melebihi standar porsi yang telah ditetapkan yaitu sebesar $83.3 \%$. keidaksesuaian standar porsi akan mempengaruhi kandungan zat gizi yang terkandung di lauk daging ayam yang disajikan kepada pasien.

Berdasarkan observasi yang dilakukan oleh peneliti, didapatkan bahwa dalam pemotongan daging ayam tidak ada penakaran khusus. Dimana pada saat penerimaan lauk daging ayam dalam keadaan sudah dipotong-potong oleh rekanan sehingga besar potongan yang dihasilkan berbeda baik dalam segi bentuk dan berat yang dihasilkan. Penimbangan daging dilakukan saat penerimaan bahan makanan dan daging dalam keadaan mentah setelah dipotong-potong.

Berdasarkan penelitian Ambarwati, R (2016) besar porsi sering sekali menjadi salah satu saat menyajikan makanan, terutama pada saat pemorsian makanan. kekurangan dan kelebihan pada saat pemorsian disebabkan karena tidak ada ukuran yang tepat dalam pemorsian makanan. pemorsian makanan harus sesuai dengan standar porsi yang telah ditentukan oleh pihak instalasi gizi Rumah Sakit. Besar porsi akan berpengaruh terhadap zat gizi yang terkandung dalam suatu makanan.

Menurut penetian yang dilakukan Eka astuti, I A (2018) Berdasarkan observasi yang dilakukan oleh peneliti lauk daging ayam tidak ditimbang kembali saat akan diolah, daging hanya ditimbang satu kali saja saat penerimaan. Petugas pemorsian juga mengatakan bahwa daging yang telah dipotong-potong tidak bisa ditambah atau dikurangi lagi saat pemorsian. Karena penambahan atau pengurangan daging ayam diluar porsi potongan daging yang telah disediakan dapat mempengaruhi tampilan estetika saat disajikan karena daging ayam akan terbelah-belah.

\section{Kesimpulan}

Dari 30 obyek yang telah dilakukan penimbangan, berat yang didapatkan tidak sesuai dengan standar porsi yang ditetapkan oleh Rumah Sakit hanya 5 (16.6\%) objek yang sesuai dan yang tidak sesuai yaitu 25 (83.3\%)pada saat melakukan penimbangan. Rata-rata berat yang dapatkan melebihi dari standar porsi yaitu 75 gram pada paha ayam dan 50 gram pada dada ayam sehingga dengan ketidaksesuaian berat bahan yang didapatkan dapat mempengaruhi kebutuhan protein pasien

Saran

Sebagai referensi untuk penelitian selanjutnya perlu mengamati tentang berat bahan pada saat penerimaan bahan makanan dengan menimbang bahan makanan yang mentah dengan cara mengambil beberapa potong ayam secara acak dan Bagi instansi tempat penelitian perlu diperhatikan berat lauk daging ayam pada saat penerimaan agar sesuai dengan standar porsi yang telah ditetapkan karena ketidaksesuaian porsi lauk daging ayam akan mempengaruhi nilai gizi yang diterima oleh pasien.

\section{Daftar Pustaka}

Almatsier, S. 2005. Penuntun Diet. Gramedia Pustaka Utama. Jakarta.

Almatsier, S. 2010. Gizi Seimbang dalam daur kehidupan. PT Gramedia pustaka utama. Jakarta.

Ambarwat, R. 2016." laporan praktikum kulyah lapangan menetapkan standar porsi dan perhitungan kebutuhan bahan makanan RSUD panembahan senopati bantul". Politekknik jurusan gizi. yogyakarta.

Astrini, R. 2017. "Hubungan karaktristik tenaga pemorsi dan alat pemorsi dengan ketepatan pemorsian mkanan pokok berdasarkan standarn porsi di Rumah Sakit PKU Muhammaddiyah Bantul”. Skripsi politekknik kesehatan kemenkes Yogyakarta.

Astuti, Ida Ayu Eka. 2018 “KTI tantang Gambaran Kesesuaian Standar Porsi Makanan Rumah Sakit Dengan Besar Porsi yang Disajikan di instalasi gizi RSUD Bahteramas Kota kendari”. Politeknik kesehatan jurasan gizi. Kendari.

Bachyar, B dkk. 2018. Sistem Penyelenggaraan Makanan Institusi. Hal 178.

Chasanah, U. 2018. Hubungan Pendidikan, Lama Bekerja Dan Pengetahuan Tentang Pemorsian Petugas Penjamah Makanan Dengan Ketepatan Porsi Makan Di Rsjd Dr. Amino Gondohutomo Provinsi Jawa Tengah. 
Departemen Kesehatan RI, 2007. Pelayanan Gizi Rumah Sakit. Departemen kesehatan RI, Jakarta. Jufri, J. 2012. “ jurnal Manajemen Pengelolaan Makanan di Rumah Sakit Umum Lanto DG Pasewang Kabupaten Jeneponto". Makasar.

Pedoman Pelayanan Gizi Rumah Sakit. 2013. Penyelenggaraan Makanan BAB V. Kementerian Kesehatan Republik Indonesia. Jakarta.

Wadyomukti, Retno Astrini. 2017."hubungan karekteristik tenaga pemorsi dan alat pemorsian dengan ketepatan pemorsian makanan pokok berdasarkan standar porsi di rumah sakit PKU Muhammadyah bantul". Politeknik jurusan gizi. Yogyakarta.

Riqi Maya R, 2009. Evaluasi Menejemen Penyelenggaraan Makanan Istitusi Di Rumah Sakit Ortopedi Prof. Dr. R Soeharso Surakarta. Universitas Muhammadiah Surakarta. 